\title{
Inclusive Teaching
}

\section{Bryan Dewsbury ${ }^{\dagger}$ and Cynthia J. Brame**}

${ }^{\dagger}$ Department of Biological Sciences, University of Rhode Island, Kingston, RI 02881; ‘ Center for

Teaching and Department of Biological Sciences, Vanderbilt University, Nashville, TN 37203

\section{ABSTRACT}

Over the past two decades, science, technology, engineering, and mathematics (STEM) faculty have been striving to make their teaching practices more inclusive and welcoming to the variety of students who enter college. However, many STEM faculty, even those at teaching-focused institutions, have been educated in a traditional environment that emphasizes research and may not include classroom teaching. This can produce a deficit in training that leaves many STEM faculty feeling uncertain about inclusive teaching practices and their essential undergirding principles. This essay describes an online, evidence-based teaching guide (https://lse.ascb.org/evidence-based-teaching-guides/inclusive-teaching) intended to help fill this gap, serving as a resource for science faculty as they work to become more inclusive, particular with regard to differences in race, ethnicity, and gender. The guide describes the importance of developing self-awareness and empathy for students as a precursor to considering classroom practices. It also explores the role of classroom climate before turning to pedagogical choices that can support students' sense of belonging, competence, and interest in the course. Finally, the guide suggests that true inclusivity is a community effort and that instructors should leverage local and national networks to maximize student learning and inclusion. Each of these essential points is supported by summaries of and links to articles that can inform these choices. The guide also includes an instructor checklist that offers a concise summary of key points with actionable steps that can guide instructors as they work toward a more inclusive practice. We hope that the guide will provide value for both faculty who are just beginning to consider how to change their teaching practices and faculty seeking to enrich their current efforts.

\section{INTRODUCTION}

There are several reasons why science, technology, engineering, and mathematics (STEM) instructors are working to provide a more inclusive experience for students in higher education. One of the most regularly cited reasons is the nagging attrition gap between students from historically disenfranchised identities and white students (Chen, 2015; Estrada et al., 2016). The evidence has been mounting for quite some time that the departure of underrepresented students from STEM majors results from reduced social belonging more than preparedness to handle the material (Seymour and Hewitt, 1997; Wilson et al., 2015). Others point to demographic shifts that will result in classrooms that are more ethnically diverse in the coming decades (Keller, 2001). This shift necessitates a critical look at STEM curricula to ensure that they reflect the diverse cultures and backgrounds in contemporary and future STEM classrooms.

As institutions of higher education refocus their efforts on improving educational outcomes for all, we find ourselves in a moment when we need to reflect on what "inclusion" really means. We define inclusivity as the practice of including people across differences, and we assert that inclusivity implies an intentional practice of recognizing and working to mitigate biases that lead to marginalization or exclusion of some people. As the culture of lecturing slowly gives way to an expansion of active learning, contemporary pedagogical methods are becoming more student focused. However, our definition of inclusion means that there is historical precedent worth
CBE Life Sci Educ June 1, 2019 18:fe2 DOI:10.1187/cbe.19-01-0021

*Address correspondence to: Cynthia J. Brame (Cynthia.brame@vanderbilt.edu).

(c) 2019 B. Dewsbury and C. J. Brame. CBE-Life Sciences Education () 2019 The American Society for Cell Biology. This article is distributed by The American Society for Cell Biology under license from the author(s). It is available to the public under an Attribution-Noncommercial-Share Alike 3.0 Unported Creative Commons License (http://creativecommons.org/licenses/ by-nc-sa/3.0)

"ASCB®" and "The American Society for Cell Biology $\circledR^{\prime \prime}$ are registered trademarks of The American Society for Cell Biology. 
considering. Specifically, the architects of critical pedagogy and pedagogy for critical consciousness have been challenging the academy to be more student centered for the past century. The educational philosopher Paolo Freire argued that instructors should build pedagogy around the voices and lives of their students (Freire, 1970), relying on ongoing dialogue with students to build classes as inclusive spaces. In this context, inclusion is built on the quality of the social relationship, which in turn relies on a knowledge of its participants.

In this essay, we describe an interactive guide created to help instructors develop inclusive teaching practices, with a particular focus on differences across race, ethnicity, and gender. The guide is found at https://lse.ascb.org/evidence-based-teaching -guides/inclusive-teaching and is based on the "deep teaching" model (Dewsbury, 2019), in which inclusive pedagogy involves being as reflective about our teaching as we expect our students to be about their learning. In this sense, inclusive teaching is not a style, but a philosophy that forms the basis of pedagogy that recognizes the whole person. This philosophy, founded in dialogue, serves as the basis upon which a respectful classroom climate is developed, progressive pedagogical techniques are implemented, and the power of the community is leveraged. These practices ideally should result in success for all students. We summarize each of these practices and their relationships to one another in the following sections.

HOW CAN INSTRUCTORS DEVELOP SELF-AWARENESS? Scientists are typically trained to make observations and gather data in a way that is as objective as possible. This training can spill over into scientists' approach to teaching, tempting instructors to try to remove the self from the learning process (Sorell, 1994). Pedagogical choices that center on lecture compound this tendency, as the focus of lecturing is expert delivery. Thus, the role that the instructors' own histories may play in the assumptions they bring to the classroom experience becomes secondary to their unidirectional task. That is, if the instructors' job is to deliver information, then who they are and the assumptions they bring are not important.

A pedagogy based on dialoguing requires a different lens. To understand students' voices, we must recognize and understand our own. This is to say, our accrued experiences from personal and social histories matter to how our relationships with our students develop. If we ignore this context, we can fail to see how we are contributing to socially disconnected classroom environments.

Developing self-awareness has implications far beyond the STEM classroom. Understanding how our at-birth identities has informed our social and professional pathways is a key component of understanding inclusive behaviors writ large (Aschaffenburg and Maas, 1997). For example, being born into a family with financial and educational privilege might better predispose an individual to pursue and attain a professional pathway. Without fully embracing that, an instructor may make erroneous assumptions on what pursuing those pathways might entail for some not born into that situation. In the context of the STEM classroom, recognizing and acknowledging our personal place in the historical stratification of higher education is necessary to create an authentic dialogue.

To develop a fuller understanding of how higher education has historically been stratified and how this has impacted them, instructors can explore the extensive work on the history of higher education and class, such as work from hooks (1994), Hurtado (1992), and Thelin (2011). This is a significant, important, and time-consuming undertaking, however, and instructors may wish to begin by thinking more directly about the classroom experience. The guide provides summaries of and links to two book chapters and an article that provide examples of a developing self-awareness (https://lse.ascb.org/ evidence-based-teaching-guides/inclusive-teaching/developing -self-awareness). These accounts emphasize that success in these engagements relies on the degree to which the instructor is willing to merge the social and the professional self.

Some key questions and challenges remain about the development of self-awareness and its relationship to inclusion.

- What is a scalable model that can characterize faculty mindset toward inclusive practices? Can this model be used to evaluate shifts in mindset? How do contextual factors affect this process?

- Is there a quantifiable connection between faculty mindset on inclusion and student academic performance and sense of belonging?

\section{HOW DO INSTRUCTORS DEVELOP EMPATHY?}

According to Freirean philosophy, dialoguing is the process by which the instructor humbly gets to know the students and their unique backgrounds (Freire, 1970). Without this, it would be impossible to design a classroom that is inclusive of their voices. As instructors work to develop dialogues with their students, knowledge of the students is a key ingredient for authenticity and potential to generate a meaningful learning experience. This is a crucial component of the process. Many models for fostering an inclusive classroom promote diversifying the learning experience through various forms of active learning (Haak et al., 2011). However, there is often less emphasis on including the voices of the students. To include students' voices, instructors should reach beyond static metrics such as incoming high school grade point average, SAT scores, and ethnic demographics and consider activities that allow the students to articulate how the experience fits into their own personal contexts. This active participation in the learning experience is what educational philosopher John Dewey refers to as educating for critical consciousness (Dewey, 1916). It is powerful because it assures students of their agency in the learning process, encouraging them to engage in reflective, personalized learning.

When instructors engage with their students' voices and acknowledge their students' agency in learning, it transforms the ways in which we construct STEM classrooms. Students' voices guide curricular choices, the support structures that help students succeed, and the tools that will promote a positive classroom climate. That is, because the students vary from classroom to classroom, the choices that promote inclusion will also vary. Categorizations of students into ethnic and other demographic bins have their uses and may be a useful starting point for instructors, but by themselves can serve to mask the nuances present in the students' unique stories.

Explicit examples of the incorporation of students' voices exist mostly in the K-12 literature (Mitra, 2004), but the guide summarizes and links some relevant studies in higher education 
that have dissected the impacts of faculty-student interactions on academic and belonging outcomes in specific scenarios (https://lse.ascb.org/evidence-based-teaching-guides/ inclusive-teaching/developing-empathy). There are two main challenges that remain pertaining to inclusion of the students' voices:

- What are the best strategies to include and incorporate the students' voices, especially in high-enrollment situations?

- How should instructors interpret the information received from the students' voices, and what specific activities should they engage in to act upon it?

\section{CLASSROOM CLIMATE}

A major result of efforts to develop empathy and dialogue with students is the development of a positive classroom climate, which is an essential component of an effective, inclusive learning environment (Freeman et al., 2007). A positive classroom climate makes students feel welcome, respected, and valued, in contrast to a negative climate that feels hostile, chilly, or chaotic (Brame, 2019). A supportive climate can help students develop a sense of belonging, which is an important-perhaps a prerequisite-element of student motivation. Students' sense of belonging within a classroom community helps them develop a value for the tasks of the class as well as a sense of competence, or self-efficacy, regarding those tasks (Zumbrunn et al., 2014). Collectively, these motivational factors predict student engagement and academic achievement. It bears repeating: A supportive classroom climate promotes students' sense of belonging, and their sense of belonging promotes their academic achievement.

When thinking about how to foster a supportive classroom and promote students' sense of belonging, instructors need to consider stereotype threat, a phenomenon described over the course of two decades by Claude Steele, Joshua Aronson, and colleagues (e.g., Steele and Aronson, 1995; O'Brien and Crandall, 2003; Murphy et al., 2007), summarized in Whistling Vivaldi (Steele, 2010). In essence, stereotype threat occurs when a person's identity as part of a negatively stereotyped group, such as African Americans in science or women in math, becomes relevant or important. Activation of the negative stereotype produces underperformance, at least in part due to the stress response that students experience because they do not want to confirm the stereotype. This phenomenon has been described across a wide spectrum of identities, can be activated by subtle cues, and matters most when students care about their performance and are doing challenging work. Fortunately, however, there are tools that instructors can deploy to help prevent and combat stereotype threat, from using language that signals an identity-safe environment to incorporating science and scientists that represent a community and its interests (Davies et al., 2005; McIntyre et al., 2003; Schinske et al., 2016). Several of these are described in both the Classroom Climate and the Fostering a Sense of Belonging sections of the guide (https://lse .ascb.org/evidence-based-teaching-guides/inclusive-teaching).

Both instructor-student and student-student interactions contribute to classroom climate, and instructors play a key role in setting a positive tone for both. Instructor warmth and respect for students can set a positive tone that welcomes students into the class and indicates that their contributions matter. The ways instructors demonstrate warmth and respect will vary, reflecting their different personalities and backgrounds; the key is to be intentional about demonstrating interest in and respect for the students in your class. Students also rate instructor organization as essential for a positive classroom climate, perhaps because instructor organization lets students know what to expect, generates a feeling of trust for the instructor, and increases the cognitive capacity they can focus on the tasks of the class.

Because interactions with peers are a key part of a positive classroom climate, one of the most important steps an instructor can take is to establish norms of mutual respect and support that govern student-student interaction in the course and to uphold those norms consistently and clearly. Building on this basis, instructors can also encourage students to interact and collaborate with one another, both in class and out of class, generating opportunities for students to recognize one another as sources of support and knowledge. The foundation of mutual respect and inclusion is critically important and may require that instructors use mechanisms that ensure that all students' contributions are heard and valued.

To help readers explore elements of classroom climate, the guide provides summaries of and links to articles that describe characteristics of positive and chilly classroom climates (https:// lse.ascb.org/evidence-based-teaching-guides/inclusive-teaching/ classroom-climate) and the role classroom climate can play in student learning. A few questions remain unexplored that could further our understanding of classroom climate.

- How do inclusive classroom climates vary in structure according to situational contexts?

- How can we quantify the relationship between the development of classroom climate and pedagogical practices?

\section{PEDAGOGICAL CHOICES}

The specific activities and methods an instructor chooses to implement in a classroom can help promote students' sense of belonging and self-efficacy (Alfasi, 2003). The guide offers summaries of and links to articles describing pedagogical approaches that may increase students' sense of belonging, engagement, and self-efficacy (https://lse.ascb.org/evidence -based-teaching-guides/inclusive-teaching/pedagogical -choices). However, it is important to recognize that these choices should be based on the experiences of the students in the classroom and a product of the developing dialogue between instructor and students. A pedagogical choice can be active, but the degree to which it reflects the instructor-student dialogue is what makes it inclusive (Dewsbury, 2017). This means that some pedagogical choices may be effective in some circumstances and inappropriate in others. For example, some educational contexts might put students at risk for stereotype threat and/or reduced social belonging. In those contexts, asking students to publicly perform their understanding may be counterproductive. It is important for instructors to consider their particular students and context when making pedagogical choices.

The underlying philosophy behind these considerations holds that the development of science identity is as crucial a part of the learning experience as the engagement of content, even when that engagement is interactive. A large body of research has developed in the past few decades that has established the 
positive effects of the explicit incorporation of identity development within the pedagogical process (Perez et al., 2014). This requires having students actively reflect on various aspects of their own personalized learning processes. Thus, making inclusive pedagogical choices in this context requires choosing options based on all the components that promote educating the whole student and not solely focusing on whether the choice is "active." As they make pedagogical choices, instructors can consider these approaches summarized in the guide and the settings in which they were investigated, focusing on making choices that can help their students develop science identity as well as to engage deeply with their content.

While the literature has shown extraordinary benefits of this intentional incorporation of affect, some questions still remain regarding the mechanisms by which those effects work.

- How might situational contexts affect the nature and psychological effects of reflection assignments?

- What are appropriate assessments that quantify the degree to which students developed sense of belonging and self-efficacy?

\section{NETWORK LEVERAGE}

Many institutions of higher education separate student life services and academic goals both physically and ideologically, thus suggesting to students that that the educational experience should be partitioned in a similar way (Frost et al., 2010). Most institutions of higher education invest substantial resources into programming, offices, events, and services aimed at improving inclusive climates. However, these services are often constructed with the assumption that students can and will self-navigate to them and are able to maximize what is available to them. The literature on social belonging for students suggests that the social belonging issues that make these services necessary also create psychological barriers for the very students who may need the services most. At least until students make authentic connections to their new learning community, it may be necessary to create a formative structure that demonstrates how these inclusive services can complement students' academic mission. Research on the power of this synergy points to freshman year experience (FYE) courses (Gardner, 1986) and living learning communities (Purdie and Rosser, 2011) as models of how academic programs can more intentionally link these services to classrooms, and the Meyerhoff Scholars program at the University of Maryland, Baltimore County, has demonstrated the power of integrating community-building experiences across students' campus experiences (Maton et al., 2016). Beyond this, inviting key campus stakeholders to visit classrooms and/or incorporating on-campus service learning modules into curricula are also effective. Additionally, it is important for the instructors to have supportive networks of their own, and it will be meaningful for instructors interested in classroom transformation to engage with organizations that provide supportive communities and materials throughout the change process. The guide provides summaries of and links to work describing ways to integrate student support services and students' academic endeavors as well as support structures for instructors (https://lse.ascb.org/evidence -based-teaching-guides/inclusive-teaching/network-leverage). However, because most institutions are still traditionally structured, a few challenges remain in understanding the full potential of leveraging campus networks.

- How can STEM course designers balance explicit incorporation of broader campus inclusive practices with the demands of high-content volume disciplines?

- In what specific ways are classroom visits by campus service providers beneficial to the social and academic experiences of STEM students?

- How do supportive faculty networks engender mindset change that promotes inclusive classrooms?

\section{CONCLUSION}

Inclusive teaching is most effective when the academic experience is based on relationships and dialogue. The other components that stem from that dialogue point to the environment (climate) and activities (pedagogy) created to sustain the dialogue, as well as the external resources leveraged to support it. These components necessarily overlap. Pedagogical practices that improve sense of belonging and self-efficacy help reinforce a classroom climate that is inclusive. FYE courses that explicitly address the development of STEM identities are key to improving a sense of belonging. In this sense, these components are not entirely discrete. However, practitioners should be particularly mindful of their professional contexts. Our guide provides a framework for how we should think about inclusion. How these elements manifest depends on the nature of the participants in the dialogue. Inclusive classrooms are necessary, because equitable education does not privilege one demographic over the other. More importantly, it is only through dialoguing and inclusion that STEM education can be fully reflective of the holistic and diverse human experience.

\section{ACKNOWLEDGMENTS}

We gratefully acknowledge Adele Wolfson and Kristy Wilson for their thoughtful and very useful review. We also thank William Pierce and Thea Clarke for their efforts in producing the Evidence-Based Teaching Guides website.

\section{REFERENCES}

Alfasi, M. (2003). Promoting the will and skill of students at academic risk: An evaluation of an instructional design geared to foster achievement self-efficacy and motivation. Journal of Instructional Psychology, 30(1), 28-40.

Aschaffenburg, K., \& Maas, I. (1997). Cultural and educational careers: The dynamics of social reproduction. American Sociological Review, 62 , 573-587.

Brame, C. J. (2019). Inclusive teaching: Creating a welcoming, supportive classroom environment. In Science teaching essentials: Short guides to good practice (pp. 3-14). San Diego: Elsevier/Academic Press.

Chen, X. (2015). STEM attrition among high-performing college students: Scope and potential causes. Journal of Technology and Science Education, 5(1), 41-59.

Davies, P. G., Spencer, S. J., \& Steele, C. M. (2005). Clearing the air: Identity safety moderates the effects of stereotype threat on women's leadership aspirations. Journal of Personal and Social Psychology, 88, 276-287.

Dewey, J. (1916). Democracy and education. New York: Macmillan.

Dewsbury, B. M. (2017). Context determines strategies for "activating" the inclusive classroom. Journal of Microbiology \& Biology Education, 18(3). 18.3.66.

Dewsbury, B. M. (2019). Deep teaching: A conceptual model for inclusive approaches to higher education STEM pedagogy. Cultural Studies in Science Education. doi.org/10.1007/s11422-018-9891-z 
Estrada, M., Burnett, M., Campbell, A. G., Campbell, P. B., Denetclaw, W. F., Gutiérrez, C. G., ... Okpodu, C. M. (2016). Improving underrepresented minority student persistence in STEM. CBE-Life Sciences Education, 15(3), es5

Freeman, T. M., Anderman, L. H., \& Jensen, J. M. (2007). Sense of belongingness of college freshmen at the classroom and campus levels. Journal of Experimental Education, 75, 203-220.

Freire, P. (1970). Pedagogy of the oppressed. (M. B. Ramos, Trans.). (p. 2007). New York: Continuum.

Frost, R. A., Strom, S. L., Downey, J., Schultz, D. D., \& Holland, T. A. (2010) Enhancing student learning with academic and student affairs collaboration. Community College Enterprise, 16(1), 37-51.

Gardner, J. N. (1986). The freshman year experience. College and University, 61(4), 261-274.

Haak, D. C., HilleRisLambers, J., Pitre, E., \& Freeman, S. (2011). Increased structure and active learning reduce the achievement gap in introductory biology. Science, 332, 1213-1216.

hooks, b. (1994). Teaching to transgress: Education as the practice of freedom. New York: Routledge.

Hurtado, S. (1992). The campus racial climate: Contexts of conflict. Journa of Higher Education, 63(5), 539-569.

Keller, G. (2001). The new demographics of higher education. Review of Higher Education, 24(3), 219-235

Maton, K. I., Beason, T. S., Godsay, S., Sto. Domingo, M. R., Bailey, T. C., Sun S., \& Hrabowski, F. A. (2016). Outcomes and processes in the Meyerhoff Scholars program: STEM PhD completion, sense of community, perceived program benefit, science identity, and research-self-efficacy. CBE-Life Sciences Education, 15, ar48.

Mclntyre, R. B., Paulson, R., \& Lord, C. (2003). Alleviating women's mathematics stereotype threat through salience of group achievements. Journal of Experimental Social Psychology, 39, 83-90.

Mitra, D. L. (2004). The significance of students: Can increasing "student voice" in schools lead to gains in youth development? Teachers College Record, 106, 651-688.
Murphy, M. M., Steele, C. M., \& Gross, J. J. (2007). Signaling threat: Cuing social identity threat among women in a math, science, and engineering setting. Psychological Science, 18, 879-885.

O'Brien, L. T., \& Crandall, C. S. (2003). Stereotype threat and arousal: Effects on women's math performance. Personality and Social Psychology Bulletin, 29, 782-789.

Perez, T., Cromley, J. G., \& Kaplan, A. (2014). The role of identity development, values, and costs in college STEM retention. Journal of Educational Psychology, 106(1), 315-329.

Purdie, J. R., \& Rosser, V. J. (2011). Examining the academic performance and retention of first-year students in living-learning communities and firstyear experience courses. College Student Affairs Journal, 29(2), 95.

Schinske, J. N., Perkins, H., Snyder, A., \& Wyer, M. (2016). Scientist Spotlight homework assignments shift students' stereotypes of scientists and enhance science identity in a diverse introductory science class. CBE-Life Sciences Education, 15(3), ar47.

Seymour, E., \& Hewitt, N. M. (1997). Talking about leaving: Why undergraduates leave the sciences. Boulder, CO: Westview.

Sorell, T. (1994). Scientism: Philosophy and the Infatuation with Science. London: Routledge.

Steele, C. M. (2010). Whistling Vivaldi: How stereotypes affect us and what we can do. New York: Norton.

Steele, C. M., \& Aronson, J. (1995). Stereotype threat and the intellectual test performance of African Americans. Journal of Personality and Social Psychology, 69, 797-811.

Thelin, J. R. (2011). A history of American higher education (2nd ed.). Baltimore, MD: Johns Hopkins University Press.

Wilson, D., Jones, D., Bocell, F., Crawford, J., Kim, M. J., Veilleux, N., ... Plett, M. (2015). Belonging and academic engagement among undergraduate STEM students: A multi-institutional study. Research in Higher Education, 56(7), 750-776.

Zumbrunn, S., McKim, C., Buhs, E., \& Hawley, L. R. (2014). Support, belonging motivation, and engagement in the college classroom: A mixed method study. Instructional Science, 42, 661-684. 